\title{
Molecular Cloning and Expression of Candida antarctica lipase B in Corynebacterium genus
}

\author{
Tamara González ${ }^{1 *}$, Hasna Nait M'Barek ${ }^{2}$, Ahmed E. Gomaa ${ }^{1}$, Hassan Hajjaj ${ }^{2}$, Chen Zhen ${ }^{1}$, and Liu Dehua ${ }^{1}$ \\ ${ }^{1}$ Department of Chemical Engineering, Tsinghua University, Beijing 100084, P.R. China \\ ${ }^{2}$ Laboratory of Plant Biotechnology and Molecular Biology, Faculty of Sciences, Moulay Ismail University, Meknes, Morocco
}

Received: May 8, 2019 / Revised: September 4, 2019 / Accepted: September 4, 2019

This study, for the first time, reports the functional expression of lipase B derived from the yeast Candida antarctica (CALB) in Corynebacterium strain using the Escherichia coli plasmid PK18. The CALB gene fragment encoding a 317-amino-acid protein was successfully obtained from the total RNA of C. antarctica. CALB was readily produced in the Corynebacterium strain without the use of induction methods described in previous studies. This demonstrated the extracellular production of CALB in the Corynebacterium strain. CALB produced in the Corynebacterium MB001 strain transformed with pEC-CALB recombinant plasmid exhibited maximum extracellular enzymatic activity and high substrate affinity. The optimal $\mathrm{pH}$ and temperature for the hydrolysis of 4-nitrophenyl laurate by CALB were 9.0 and $40^{\circ} \mathrm{C}$, respectively. The enzyme was stable at $\mathbf{p H} 10.7$ in the glycine-KOH buffer and functioned as an alkaline lipase. The CALB activity was inhibited in the presence of high concentration of $\mathrm{Mg}^{2+}$, which indicated that CALB is not a metalloenzyme. These properties are key for the industrial application of the enzyme.

Keywords: Candida antarctica lipase B, Corynebacterium genus, protein engineering, extracellular enzymatic activity, biochemical characterization

\section{Introduction}

For the production of heterologous proteins, several cell factories have been developed and applied for different purposes. Each system has its own advantages, but also possible drawbacks. No doubt, a major advantage of using Gram-positive bacteria is that target proteins, when equipped with the necessary secretion system, can be secreted outside of the cell enabling correct folding and accompanying functionality as such facilitating downstream processing. As secretion yield is very important to make the process economically viable, several attempts to improve the secretion process have been reported [1].

\section{*Corresponding author}

Tel: +86 13718036057

E-mail: tamy.glez@yahoo.com

๑) 2019, The Korean Society for Microbiology and Biotechnology
With this purpose, the engineering of the Lipase B from Candida antarctica (CALB) is an urgent issue, necessary to obtain better properties by protein engineering approaches. It is therefore an attractive and challenging goal for many researchers. CALB is a macromolecule with a molecular mass of about $33 \mathrm{kDa}$ and 317 amino acid residues in its polypeptide chain [2]. This extracellular enzyme is one of the most widely used biocatalysts [3].

CALB has been cloned and expressed in different hosts, such as Aspergillus oryzae, Pichia pastoris, Saccharomyces cerevisiae, Escherichia coli and Yarrowia lipolytica [4]. However, to date there are no reports describing the gene cloning and level expression of CALB in Corynebacterium genus. Several problems, including generation of insoluble proteins in E. coli, low secretion efficiency in $S$. cerevisiae, and poor transformation efficiency in $P$. pastoris, have limited the develop- 
ment of efficient screening protocols and thus the identification of CALB variants with interesting properties [3]. On the other hand, gram-positive bacteria are considered to be more suitable for whole-cell catalysts and whole-cell adsorbents because of the robust structure of their cell walls.

Studies in E. coli have shown that the ability to control the activity of the promoter is an absolute prerequisite for maintaining a stable expression plasmid in the host [5]. These studies were based on the Escherichia coli plasmids pK18 and pK19 by combining the useful properties of the pK plasmids (e.g., multiple cloning site, lacZ $\alpha$ fragment, sequencing with M13 primers) with the broad-host-range transfer machinery of plasmid RP4. New pK derivatives can be transferred by RP4-mediated conjugation into a wide range of Gram negative and positive bacteria and should facilitate gene disruption and allelic exchange by homologous recombination [6] .

Corynebacterium genus is asporogenous Grampositive bacteria with moderately high $\mathrm{G}+\mathrm{C}$ content. A wild type of these bacteria is widely used as producers of amino acids. Recently, Corynebacterium glutamicum has attracted attention as a potential cell factory for the production of recombinant proteins since it exhibits numerous ideal features for protein secretion $[7,8]$. First, as a Gram-positive bacterium, it has a single cellular membrane, which allows proteins to be secreted into the extracellular medium by simply crossing a single membrane barrier. Second, C. glutamicum secretes only a few endogenous proteins into the culture medium, which allows for the simple purification of target proteins in downstream process compared to the protein production and purification processes of other bacterial hosts such as Escherichia coli. Third, secreted proteins from C. glutamicum can be kept stable because extracellular protease activity is rarely detectable [9]. Fourth, it is capable of much more protein secretion than the dozen or so documented to date [10]. All these characteristics make $C$. glutamicum a very favorable and versatile host for heterologous protein productions.

There had been only few reports concerning heterologous protein secretion in C. glutamicum [10-12], but recent studies indicated that $C$. glutamicum indeed possesses a variety of secretory proteins [8, 13, 14]. Based on secretome analysis of C. glutamicum, Yim et al. [9] identified one major protein encoded by cg1514 and demonstrated that a secretome analysis can be a useful method for discovering overexpressed proteins in extracellular medium.

Taking into account all of the above mentioned ideas, in the present investigation we report the successful cloning, expression and partial biochemical characterization of CALB produced in culture supernatant from $C$. antarctica in Coryneform strain expression system.

\section{Materials and Methods}

\section{Bacterial strains, plasmids, chemicals, media and growth conditions}

Candida antarctica strain, C. glutamicum S9114, C. glutamicum MB001, C. ammoniagenes ATCC 6872, Escherichia coli DH5 $\alpha$ cells and plasmid pUC18 used in this study were purchased from TSINGKE Company. All CALB expression systems were designed and constructed on the basis of the wild type of Corynebacteria strains that encoded one major protein from efficient protein secretion.

Candida antarctica was routinely cultivated at 200 rpm and $30^{\circ} \mathrm{C}$ in Luria-Bartani (LB) medium (per $1 \mathrm{~L}$ distilled sterile water): $10 \mathrm{~g}$ tryptone, $5 \mathrm{~g}$ yeast extract, $10 \mathrm{~g} \mathrm{NaCl}$ and $50 \mathrm{mg}$ kanamycin. Epo medium was used for Corynebacterium strains growth and electroporation of competent cells [6] (per $100 \mathrm{ml} \mathrm{LB}$ medium): $1 \mathrm{~g}$ tryptone, 0.5 g yeast extract, $1 \mathrm{~g} \mathrm{NaCl}, 400 \mathrm{mg}$ isonicotinic acid hydrazide (isoniazid), $2.5 \mathrm{~g}$ glycine and $0.1 \mathrm{ml}$ Tween 80.

BHIS (Brain Heart Infusion, Sorbitol) medium (per $1 \mathrm{~L}$ distilled sterile water): $5 \mathrm{~g}$ tryptone, $5 \mathrm{~g} \mathrm{NaCl}, 2.5 \mathrm{~g}$ yeast extract, $18.5 \mathrm{~g}$ Brain Heart Infusion powder (Difco), all autoclaved together, and separately autoclaved $91 \mathrm{~g}$ sorbitol [16]. LBHIS plates for growth of transformants were composed of BHIS medium, adding (per $1 \mathrm{~L}$ ) $15 \mathrm{~g}$ agar and $25 \mathrm{mg}$ kanamycin.

CGXII medium [9] for the expression of CALB in shake flasks was composed of (per $1 \mathrm{~L}$ distilled sterile water): $40 \mathrm{~g}$ glucose, $20 \mathrm{~g}$ (NH4) ${ }_{2} \mathrm{SO}_{4}, 5 \mathrm{~g}$ urea, $1 \mathrm{~g}$ $\mathrm{KH}_{2} \mathrm{PO}_{4}, 1 \mathrm{~g} \mathrm{~K} \mathrm{HPO}_{4}, 0.25 \mathrm{~g} \mathrm{MgSO}_{4} \cdot 7 \mathrm{H}_{2} \mathrm{O}, 42 \mathrm{~g} 3-$ morpholino-1-propanesulfonic acid (MOPS), $10 \mathrm{mg} \mathrm{CaCl}$, $10 \mathrm{mg} \mathrm{FeSO} \cdot \cdot 7 \mathrm{H}_{2} \mathrm{O}, 10 \mathrm{mg} \mathrm{MnSO}_{4} \cdot \mathrm{H}_{2} \mathrm{O}, 1 \mathrm{mg} \mathrm{ZnSO}{ }_{4} \cdot$ $7 \mathrm{H}_{2} \mathrm{O}, 310 \mu \mathrm{g} \mathrm{CuSO} \cdot \cdot 5 \mathrm{H}_{2} \mathrm{O}, 20 \mu \mathrm{g} \mathrm{NiCl} \cdot 6 \mathrm{H}_{2} \mathrm{O}, 200 \mu \mathrm{g}$ Biotin, $30 \mathrm{mg}$ Protocatechuic acid (PCA) and $25 \mathrm{mg}$ Kanamycin. $2 \mathrm{M} \mathrm{KOH}$ was used to adjust pH 7.0 [17]. 


\section{Cloning and sequencing of lipase gene}

Candida antarctica cells were harvested after overnight culture in LB medium. Chromosomal DNA was obtained using TIANamp Genomic DNA Kit (DP304, TIANGEN China) according to manufacturer protocol and amplified by PCR. All PCR experiments were performed using Thermal Cycler $\mathrm{S} 1000^{\mathrm{TM}}$ (Biorad, USA). Briefly, $50 \mu \mathrm{l}$ PCR reaction mixture included $25 \mu \mathrm{l}$ I- $5^{\mathrm{TM}}$ $2 \mathrm{X}$ High Fidelity Master Mix, $2 \mu \mathrm{l}$ plasmid template, $2 \mu \mathrm{l}$ forward primer and $2 \mu \mathrm{l}$ reverse primer (primer sequences are available in Table 1). For the initial denaturation, the mixture was first heated to $98^{\circ} \mathrm{C}$ for $2 \mathrm{~min}$. This was followed by 30 cycles of denaturation at $98^{\circ} \mathrm{C}$ for $10 \mathrm{~s}$, annealing at $60^{\circ} \mathrm{C}$ for $15 \mathrm{~s}$, elongation at $72^{\circ} \mathrm{C}$ for $1 \mathrm{~min}$ per $\mathrm{kb}$ of template length with the final elongation step at $72^{\circ} \mathrm{C}$ for $5 \mathrm{~min}$.

DNA fragments were ran in $1 \%$ agarose gel and the band with 6-7 kb range identified by molecular weight marker was carefully cut from the gel. It was purified by GeneJET Gel Extraction Kit (Thermo Scientific, USA) followed by Gibson Assembly Master Mix (New England Biolabs, China) for successful assembly of DNA fragments.

For secretory production, two plasmids were constructed for CALB expression: $p E C-C A L B$ and $p E C-$
H36-CALB. For pEC-CALB, M-13F and M-13R primers containing SacI and XbaI restriction sites were used. Plasmid pEC-H36-CALB was made based on pECCALB and pK18-lysC vector using V-F and V-R. PH36 fragment was extended in front of the cg1514 signal sequence by PCR with primers H36-F and H36-R. Plasmids design was conducted using the sequence analysis software SnapGene Viewer (Version 3.1.2.0, GSL Biotech LLC, USA) as shown in Figure A in supplementary material. All sequences used in this study are listed in Table 1. Recombinant plasmids were transformed by heat shock with competent $E$. coli DH5 $\alpha$ cells. Colonies containing clones with insert were selected to check for the correct insert size and analyzed by agarose gel electrophoresis. New plasmids were extracted by Mini Plasmid Extraction Kit and samples were sent to a sequencing laboratory. DNA concentration and purity were determined by measuring absorbance at $260 \mathrm{~nm}$ and $280 \mathrm{~nm}$ using a Multiskan GO Thermo Scientific, version 1.00.40, USA.

\section{Preparation of bacterial competent cells and transforma- tion}

Transformation of Corynebacterium competent cells was carried out using the procedure of M. E. van der

Table 1. Bacterial strains and plasmids used in this study.

\begin{tabular}{|c|c|c|}
\hline Material used & Relevant characteristic & Reference or source \\
\hline \multicolumn{3}{|l|}{ Strain } \\
\hline C. glutamicum & Wild type & S9114 \\
\hline C. glutamicum & Wild type & MB001 \\
\hline C. ammoniagenes & Wild type & ATCC6872 \\
\hline E Coli DH5a & $\begin{array}{l}\text { F- } \varphi 80 \text { lacZ } \triangle \mathrm{M} 15 \Delta \text { (lac ZYA-argF)endA1, recA1hsdR17 }\left(r_{k}-m_{k}+\right) \operatorname{supE} 44 \lambda \text {, } \\
\text { thi-1 gyrA96 rel } A 1 \text {, phoA }\end{array}$ & $\begin{array}{l}\text { TIANGEN BIOTECH } \\
\text { CE1200227 }\end{array}$ \\
\hline \multicolumn{3}{|l|}{ Plasmids } \\
\hline pEC-CALB & $\begin{array}{l}\text { 7023bp Linearized vector plasmid containing an E. coli origin of replication, } \\
\text { kan and PCR fragment of cg1514 (5782-5877) }\end{array}$ & This work \\
\hline $\mathrm{pEC}-\mathrm{H} 36-\mathrm{CALB}$ & 7112bp containing plasmid Pec-CALB and H36 promoter & Yim et al. [2016] \\
\hline \multicolumn{3}{|l|}{ Primers } \\
\hline M13F & 5'- ATGTTAAACAGAGTCAGTCGTATTGCAGG -3' & This work \\
\hline M13R & 5'- CTCCTGATCATGTAGGTGTCCTGAAA - $3^{\prime}$ & This work \\
\hline $\mathrm{H} 36-\mathrm{F}$ & 5'- GACACCTACATGATCAGGAGCAAAAGCTGGGTACCTCTATCTG -3' & This work \\
\hline $\mathrm{H} 36-\mathrm{R}$ & 5'- CGACTGACTCTGTTTAACATGGATCCCATGCTACTCCTACC -3’ & This work \\
\hline V-F & 5'- CTCCTGATCATGTAGGTGTCCTGAAA -3' & \\
\hline V-R & 5'- ATGTTAAACAGAGTCAGTCGTATTGCAGG -3' & \\
\hline
\end{tabular}


Rest et al. [16]. Briefly, Corynebacterium genus was inoculated in LB medium with $2 \%(\mathrm{w} / \mathrm{v})$ glucose, cultivated overnight and used for the inoculation of Epo medium. The latter was centrifuged and Corynebacteria cells were stored in $10 \%(\mathrm{v} / \mathrm{v})$ ice-cold glycerol at $-70^{\circ} \mathrm{C}$. Thawed cells were mixed with DNA and electroporated using a Gene Pulser Xcell electroporation system (BioRad, USA). After that, optimal heat transfer was conducted at $46^{\circ} \mathrm{C}$ in BHIS medium. Recovery and expression of the antibiotic resistance marker was assured by incubation at $30^{\circ} \mathrm{C}, 300 \mathrm{rpm}$ for $3 \mathrm{~h}$ in a dry block (Thermomixer F1.5) and Corynebacteria cells possessing the plasmid were selected on solid LBHIS plates.

\section{Expression of CALB in shake flasks}

Different recombinant Corynebacteria colonies from LBHIS plates were used to inoculate CGXII medium. $40 \mathrm{ml}$ cells was cultivated in a shaker incubator (SUKUN SKY-211B, China) at $30^{\circ} \mathrm{C}$ and $200 \mathrm{rpm}$ for $72 \mathrm{~h}$. Controls from different Corynebacteria were run to enable comparison of results.

Protein quantification was conducted using the BCA (bicinchoninic acid) protein assay kit (LEAGENE, China). A 96 well plate procedure was adopted according to the manufacturer's instructions and Bovin Serum Albumin (BSA) was used as standard. Absorbance was read at $562 \mathrm{~nm}$ in Multiskan.

\section{SDS-PAGE analysis}

For quantification of the expressed lipase, the culture supernatant was analyzed using SDS-PAGE on a $5 \%$ acrylamide stacking gel and 10\% separating gel using a Mini-gel system (Bio-Rad). Gels were cast with $0.75 \mathrm{~mm}$ spacers, samples were mixed with $2 \mathrm{X}$ reducing loading buffer and heated at $100^{\circ} \mathrm{C}$ for $5 \mathrm{~min}$ before electrophoresis. About $2 \mu \mathrm{g} / \mu \mathrm{l}$ were deposited in each well. Proteins in the gel were stained with Coomassie brilliant blue G250 and distained by heating in water in a microwave oven [18].

\section{Fed-batch fermentation conditions}

Bioreactor cultivation. Fed-batch cultivations were carried out using the procedure of Yim et al. [9]. For secretory analysis of CALB, culture medium was centrifuged at $5000 \mathrm{~g}, 4^{\circ} \mathrm{C}$ for $10 \mathrm{~min}$, supernatant concentrated 19 times using $10 \mathrm{~K}$ Centricon filters and CALB production was followed up in time by SDS-PAGE. Protein quantification was done using a Molecular Imager ${ }^{\circledR}$ Gel Doc ${ }^{\mathrm{TM}}$ XR+ System with Image Lab ${ }^{\mathrm{TM}}$ Software (BioRad). For glucose quantification, supernatant was 0.2 $\mu \mathrm{m}$ filtered and injected in HPLC-RI system (SHIMADZU Instruments, CTO-20A model, Japan). Aminex HPX-87H column (Bio-Rad, Laboratories, Inc., USA) was used at $65^{\circ} \mathrm{C}$ and $5 \mathrm{mM} \mathrm{H} \mathrm{H}_{2} \mathrm{SO}_{4}$ mobile phase at $0.8 \mathrm{ml} / \mathrm{min}$.

\section{Lipase activity determination with titrimetric method.}

This method was used to determine the enzymatic activity over time in bioreactor cultures. It is based on the titrimetric determination of free fatty acids released from triacylglycerols by lipase-catalyzed hydrolysis. Reaction mixture consisted of $1 \mathrm{ml}$ tributyrin (TCI, Japan) as enzyme substrate, $3 \mathrm{ml}$ of $0.05 \mathrm{M}$ glycine-NaOH buffer (pH 9.0) and $0.1 \mathrm{ml}$ enzyme supernatant. Flasks were incubated at $45^{\circ} \mathrm{C}, 175 \mathrm{rpm}$ for $10 \mathrm{~min}$ and $50 \mathrm{ml}$ ethanol was added to terminate the reaction. The released fatty acids were estimated by titration with $0.05 \mathrm{M} \mathrm{NaOH}$ in the presence of Phenolphthalein. Negative (without enzyme) and positive (Novozym 435, China) controls were considered. One unit activity was defined as the amount of enzyme capable of releasing $1 \mu \mathrm{mol}$ fatty acid, per minute and under the test conditions. Lipase activity was calculated using the following formula:

Lipase activity $=$

$$
\frac{\text { Vol. of } \mathrm{NaOH} \text { consumed }(\mathrm{ml}) \times \text { Molarity of } \mathrm{NaOH}}{\text { Vol. of Lipase }(\mathrm{ml}) \times \text { Reaction Time }(\min )}
$$

Lipase activity assay with 4-nitrophenyl laurate. This assay was used to determinate biochemical characteristics of Lipase B from bioreactor cultivation of $C$. glutamicum MB001/pEC-CALB. The spectrophotometric method make use of synthetic substrates, which are transformed upon enzyme-catalyzed hydrolysis into spectrophotometrically detectable products. Because lipase B has maximal activity on laurate [21], 4-nitrophenyl laurate (4-NPL) was selected as substrate and the activity was assayed by a modified method [20] in 96 well plate with Multiskan, (Thermo Scientific version 1.00.40, USA). The reaction mixture consisted of $0.65 \mathrm{ml}$ of $0.05 \mathrm{M}$ phosphate buffer ( $\mathrm{pH} 7.2), 0.1 \mathrm{ml}$ enzyme supernatant and $0.1 \mathrm{ml}$ of $0.025 \mathrm{M} 4-\mathrm{NPL}$ prepared in 
absolute ethanol. The hydrolytic reaction was carried out at $65^{\circ} \mathrm{C}$ for $30 \mathrm{~min}$ and then terminated adding 0.25 ml of $0.1 \mathrm{M} \mathrm{Na}_{2} \mathrm{CO}_{3}$. After centrifugation, absorbance was read at $410 \mathrm{~nm}$ and lipase activity was calculated using the following formula:

Enzymatic activity $(\mu \mathrm{moles} / \mathrm{min})=$

$$
\frac{V(\mu \mathrm{l}) \times \mathrm{OD} 410 \mathrm{~nm}\left(\mathrm{~cm}^{-1}\right)}{\varepsilon \times \text { incubation time }(\mathrm{min})}
$$

Under the conditions used, the extinction coefficient of 4-nitrophenol was $\varepsilon=7.15 \mathrm{mM}^{-1} \times \mathrm{cm}^{-1}$. One unit activity was defined as the amount of enzyme capable of releasing $1 \mu \mathrm{mol} 4$-nitrophenol, per minute under the assay conditions.

Effect of temperature on activity. Effect of temperature on lipase B activity produced by C. glutamicum MB001/ pEC-CALB was studied at temperatures ranging from 30 to $80^{\circ} \mathrm{C}$ in $0.05 \mathrm{M}$ phosphate buffer ( $\mathrm{pH} 7.2$ ) using 4-NPL assay. Enzyme was incubated in the presence of substrate for $30 \mathrm{~min}$ and the activity was measured. Optimum temperature for CALB activity was determined.

Effect of pH on enzyme activity. The $\mathrm{pH}$ effect on CALB activity from C. glutamicum MB001/pEC-CALB was studied in a $\mathrm{pH}$ range of 3.0-9.0 using different buffer systems (50 mM): citric acid-sodium citrate buffer $(\mathrm{pH}$ 3.0-5.0), Phosphate Buffer Saline (PBS, pH 4.6-7.5) and Glycine-KOH buffer ( $\mathrm{pH}$ 9.0). Activity was measured using 4-NPL assay at optimum temperature for CALB activity $\left(40^{\circ} \mathrm{C}\right)$.

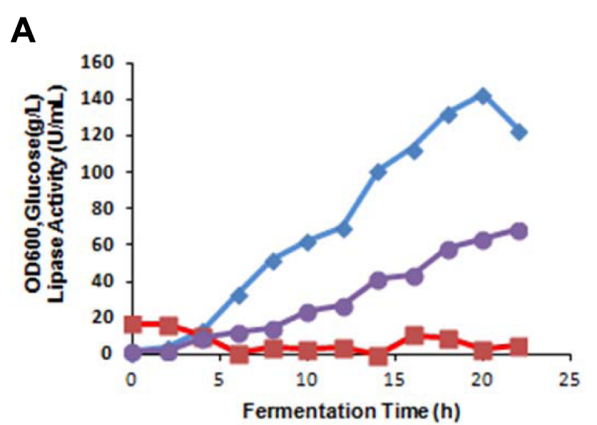

Effect of metal ions. Certain enzymes require a metal ion for their optimal activity. As reported from studies on this isolate, some metal ions could affect the enzyme activity at determinate concentration [25].

The effect of two concentrations ( 1 and $10 \mathrm{mM}$ ) of various metal ions on CALB activity of C. glutamicum MB001/pEC-CALB was investigated using $\mathrm{Mg}^{2+}, \mathrm{Fe}^{2+}$, $\mathrm{Mn}^{2+}, \mathrm{Zn}^{2+}$ and $\mathrm{Ca}^{2+}$. The enzyme was treated with the latter at $40^{\circ} \mathrm{C}$ for $30 \mathrm{~min}$ in $0.05 \mathrm{M}$ phosphate buffer (pH 7.2). The relative activity was measured under the 4-NPL standard assay conditions. Sample without the addition of metal ions and surfactants was taken as control (100\%) and all samples were analyzed in duplicates.

\section{Results}

\section{Cloning, expression and Sequence Analysis of CALB gene}

The new obtained fragment encoded a putative protein of 317 amino acids with a molecular mass of $33 \mathrm{kDa}$ and fragment size of $7023 \mathrm{bp}$ (Fig. B, Supplementary material). Successful cloning was confirmed by sequencing of the isolated plasmids and analysis in 1\% agarose gel. A multisequence alignment using BLAST showed that pEC-CALB had $80 \%$ amino acid sequence identity with the CALB from C. antarctica (LF 058) gene for lipase B, accession No Z30645.1.

Analysis of recombinant lipase from Corynebacteria genus. The absorbance values from S9114/pEC-CALB, MB001/pEC-CALB, ATCC6872/pEC-CALB, S9114/pECH36-CALB, MB001/pEC-H36-CALB and ATCC6872/ pEC-H36-CALB were 25.58, 20.54, 13.44, 17.66, 14.12

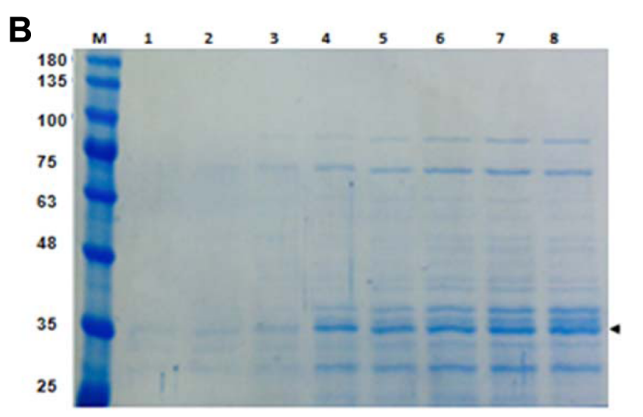

Fig. 1. Fed-batch cultivation of C. glutamicum MB001 producing CALB. (A) Time profiles of cell growth ( $\diamond)$, glucose concentration ( $\square$ ), and Enzymatic Activity ( $O$ ) in the culture supernatant. (B) SDS-PAGE analysis of culture supernatant during fed-batch cultivation. M: molecular mass marker proteins. Lanes 1 to 8 , samples at 2, 4, 6, 10, 16, 18, 20 and $22 \mathrm{~h}$, respectively. At each time point, $12 \mu \mathrm{l}$ of samples (without concentration) was loaded onto each lane. The arrowhead indicates CALB (33 kDa). 
A

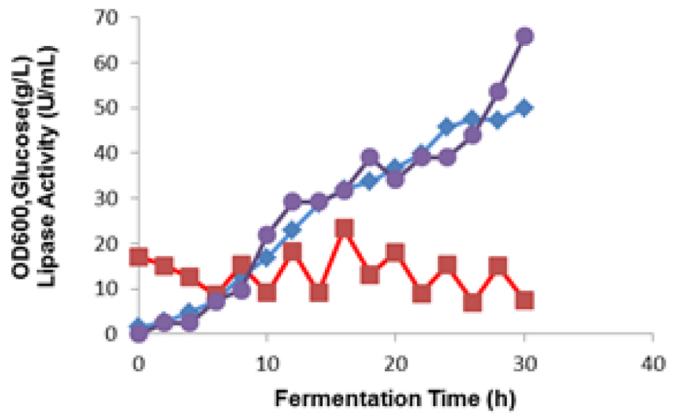

B

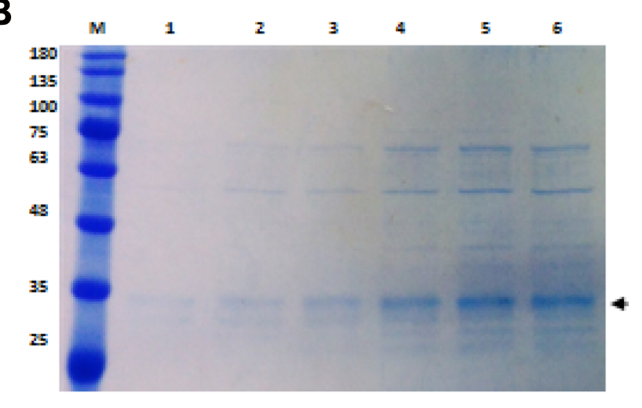

Fig. 2. Fed-batch cultivation of $\mathbf{C}$. glutamicum $\mathbf{S 9 1 1 4}$ producing CALB. (A) Time profiles of cell growth ( $\diamond)$, glucose concentration ( $\square$ ), and Enzymatic Activity ( $)$ in the culture supernatant. (B) SDS-PAGE analysis of culture supernatant during fed-batch cultivation. M: molecular mass marker proteins. Lanes 1 to 6, samples at 4, 6, 10, 16, 24 and $30 \mathrm{~h}$, respectively. At each time point, $12 \mu \mathrm{l}$ of samples (without concentration) was loaded onto each lane. The arrowhead indicates CALB (33 kDa).

and $24.58 \mathrm{UFC} / \mathrm{ml}$, respectively. Mutant lipase samples showed several bands like the controls, but also a distinctive band estimated to be approximately $35 \mathrm{kDa}$ corresponding to the secretory productions of CALB. This is consistent with the predicted molecular weight of lipase $(33 \mathrm{kDa})$. Comparable molecular weights have also been reported from other studies [4-6, 9, 15, 22-24]. Strain S9114 has another strong band about $50 \mathrm{kDa}$ position but the corresponding sequence was not identified in the database. By measuring the intensities of the bands obtained in the SDS-PAGE, it was possible to estimate the CALB lipase content in supernatant (Fig. C, Supplementary material). Results for S9114/pEC-CALB, MB001/pEC-CALB and ATCC6872/pEC-CALB showed in figure $\mathrm{C}(1)$ were about $27 \%, 22 \%$ and $16 \%$ of the total protein, respectively. Of the three pEC-H36-CALB transformants that we constructed only one secreted in C. glutamicum MB001, as shown in Fig. C(2).

According to absorbance values and SDS-PAGE results, fed-batch cultivations were carried out for S9114/pEC-CALB and MB001/pEC-CALB. The secretory production yields were analyzed. C. glutamicum MB001 harboring pEC-CALB entered exponential growth at $6 \mathrm{~h}$. The cells significantly increased to $\mathrm{OD}_{600}$ 142.6 UFC/ml for $20 \mathrm{~h}$ with specific growth rate of $0.4906 \mathrm{~h}^{-1}$ in the exponential growth phase and then decreased (Fig. 1A). In the case of fed-batch cultivation of C. glutamicum S9114, it continued to grow up to $\mathrm{OD}_{600}$ of $50 \mathrm{UFC} / \mathrm{ml}$ for $30 \mathrm{~h}$ with specific growth rate of $0.2661 \mathrm{~h}^{-1}$ in the exponential growth phase (Fig. 2A). The maximum CALB content was approximately $17 \%$ and $43.5 \%$ of the total extracellular proteins in MB001 (22 h) and S9114 (32 h), respectively, at the end of fermentation (Figs. 1B and $2 \mathrm{~B}$ ). The maximum production yield was about $5953.8 \mathrm{mg} / \mathrm{l}$ and $3191.8 \mathrm{mg} / \mathrm{l}$, which means a productivity of $297.7 \mathrm{mg} / \mathrm{l}$ and $106.4 \mathrm{mg} / \mathrm{l}$ in $1 \mathrm{~h}$ for MB001/pEC-CALB and S9114/pEC-CALB, respectively. The isolates MB001/CALB and S9114/CALB were grown in optimum culture conditions and lipase activity was observed to start soon after beginning of inoculation where the concentration gradually increased reaching a maximum activity of $68.38 \mathrm{U} / \mathrm{ml}$ and 63.44 $\mathrm{U} / \mathrm{ml}$, respectively. Taking into consideration the higher productivity and activity results of CALB from $C$. glutamicum MB001/pEC-CALB, the latter was selected for biochemical characterization of Lipase B enzyme.

\section{Characterization of the recombinant lipase}

Effect of temperature on activity. As shown in Fig. 3, the optimal temperature range was found to be from 40

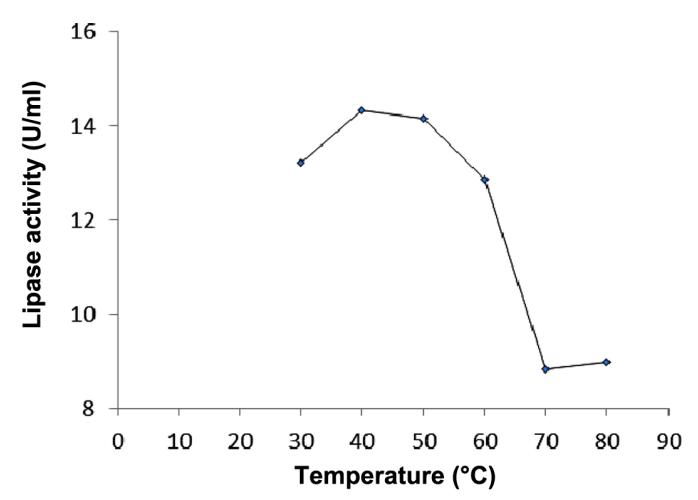

Fig. 3. Effect of temperature on the recombinant lipase. 


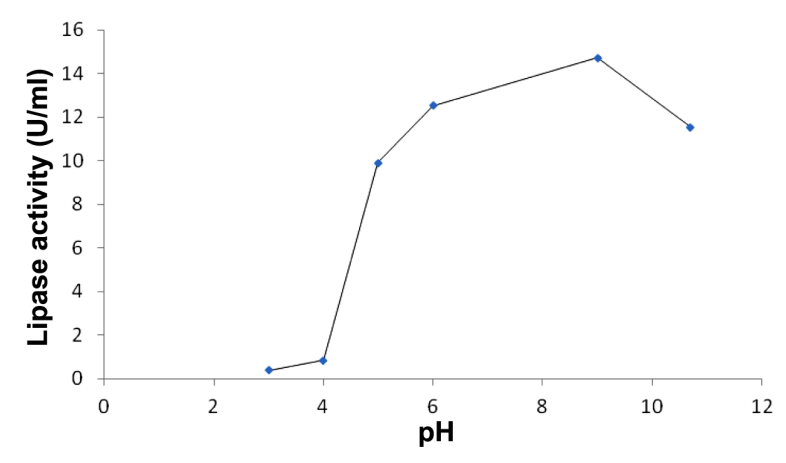

Fig. 4. Effect of pH on the activity of the recombinant lipase. Buffer systems: Citric acid-sodium citrate buffer ( $\mathrm{pH}$ 3.0-5.0), PBS buffer (pH 6), and Glycine-KOH buffer (pH 9.0-10.7).

to $50^{\circ} \mathrm{C}$, and the optimal activity was attained at $40^{\circ} \mathrm{C}$. More than $60 \%$ of the activity was lost at temperatures above $60^{\circ} \mathrm{C}$. This showed that the recombinant lipase obtained in this study was a heat-sensitive enzyme.

Optimal pH for recombinant CALB activity. The recombinant CALB was found to be most active at $\mathrm{pH}$ 9.0 in Glycine-KOH buffer and exhibited very low activity at $\mathrm{pH}$ 3-4 (Fig. 4). The activity of CALB decreased after incubation at buffer with the $\mathrm{pH}$ below 5 , while it was relatively stable in an alkaline environment.

Effect of metal ions on the lipase activity. The effect of various chemicals on CALB enzymatic activity is shown in Table 2 with 0.05 standard deviation of duplicated samples. It was not observed a significant effect using different concentrations ( $1 \mathrm{mM}$ and $10 \mathrm{mM}$ ) of $\mathrm{Fe}^{2+}$, $\mathrm{Mn}^{2+}, \mathrm{Zn}^{2+}$ and $\mathrm{Ca}^{2+}$. CALB activity was only inhibited in the presence of high concentration of $\mathrm{Mg}^{2+}$, indicating that CALB is not a metalloenzyme.

Table 2. Effect of metal ions on the activity of recombinant lipase.

\begin{tabular}{ccc}
\hline Metal ions & $\begin{array}{c}\text { \% Relative activity } \\
(1 \mathrm{mM})\end{array}$ & $\begin{array}{c}\text { \% Relative activity } \\
(10 \mathrm{mM})\end{array}$ \\
\hline Control & 100 & 100 \\
$\mathrm{MgSO}_{4}$ & 92 & 69 \\
$\mathrm{FeSO}_{4}$ & 91 & 97 \\
$\mathrm{MnSO}_{4}$ & 96 & 91 \\
$\mathrm{ZnSO}_{4}$ & 101 & 96 \\
$\mathrm{CaCl}_{2}$ & 102 & 101 \\
\hline
\end{tabular}

\section{Discussion}

This study demonstrates the ability of extracellular production of CALB in Coryneforms strain like others $[4,28]$.

The best results were obtained from the transformants in C. glutamicum S9114 and MB001. This is a favorable host for protein production and secretion because it lacks extracellular proteolytic activities [15]. The sequence analysis and the molecular weight measurement of recombinant CALB confirmed the integrity of the structure.

CALB was readily produced without the use of induction methods described in previous papers [4,6]. Our expression system was based in three important elements: Conjugation mediated by the broad-host-range (bhr), the most efficient system to introduce foreign DNA [17], the Cg1514 signal sequence directly fused to the mature portion of CALB, and the good culture medium. Their combination resulted in a successful CALB production.

A recent study compared the secretion capacity of different extracellular proteins in five types of yeasts and the results showed that Saccharomyces cerevisiae had lower secretion capacity than other yeasts such as Pichia pastoris, Kluyveromyces lactis and Yarrowia lipolytica. Longer incubation time was consequently needed before first detection of lipase activity in Saccharomyces cerevisiae (7 days compared to 2 days for Pichia pastoris). This has been attributed to the culture conditions, where the protein secretion requirements were minimal and several process parameters affected the production of recombinant proteins in yeasts. Good optimization of growth conditions should have considered how the recombinant strain was constructed. These factors combined, we can note that secretion system of C. glutamicum MB001 mutant grown in properly-optimized culture conditions remains efficient and advantageous for use in high-scale CALB production [34].

The use of the Cg1514 signal sequence for secretory expression is one major reason for the successful production. In his article [9], Yim demonstrated the feasibility of the Cg1514 based system for the secretion of proteins with a broader range of molecular weights examining different proteins. 
Cells were grown and studied in CGXII and BHI, where CGXII was the best medium because the cells grew more than BHI and the bands were clearly observed. C. glutamicum, when cultured on defined CGXII minimal medium with glucose as single carbon source, has revealed more than 800 genes that exhibited full-length or almost full-length antisense transcripts [11]. It became the standard for Metabolic Engineering and Systems Biology with C. glutamicum and has been cited over 250 times [26].

In fermenter process, CALB was successfully secreted in the culture medium with high efficiency. The maximum production yield was about $6 \mathrm{~g} / \mathrm{l}$ and $3.2 \mathrm{~g} / \mathrm{l}$ from MB001/pEC-CALB and S9114/pEC-CALB, respectively. These results were higher compared to values reported in C. glutamicum as a host [9,27]. The enzymatic activity was higher too, reaching values of 68.38 and $63.44 \mathrm{U} /$ $\mathrm{ml}$ in short time. Most studies in the literature reported lower lipase activity values in fed-batch fermentation after $100 \mathrm{~h}[4,28]$. Very few represented higher values and were obtained with the assistance of additional factors.

The characterization of lipase B from C. antarctica, tested in the presence of 4-NPL substrate, was conducted in different conditions and was compared with various expression strategies. CALB was stable at $\mathrm{pH}$ 10.7 compared with Acinetobacter species SY-01 lipase (pH 9-11) [29]. Optimum value was at $\mathrm{pH} 9$ similar to Bacillus sp LBN2 [30]. Besides, the optimum temperature $\left(40^{\circ} \mathrm{C}\right)$ is similar to Bacillus amyloliquefaciens PS35 lipase [31]. When the temperature was higher than $60^{\circ} \mathrm{C}$, the thermostability of the lipase enzyme was reduced more than $60 \%$, indicating that the recombinant lipase is moderately thermostable enzyme. These results showed that lipase production is species specific and has its own temperature optima which favored maximum enzyme production [32].

An overview of current literature demonstrates that it is difficult to predict a priori how one or another metal will influence the enzyme. This depends not only on the nature of the metal and the enzyme, but also on other specific conditions. The most important of those are various factors like the concentration of the metal [33]. During this study, it was not observed a significant effect in the concentration of metals indicating that CALB is not a metalloenzyme.

\section{Acknowledgments}

This work was developed for the Ministry of Science and Technology of China (MOST) and supported by Tsinghua University. Thanks are due to MSc. Loany Calvo for critical comments on the article.

\section{Conflict of Interest}

The authors have no financial conflicts of interest to declare.

\section{References}

1. Anné J, Vrancken K, Van Mellaert L, Van Impe J, Bernaerts K. 2014. Protein secretion biotechnology in Gram-positive bacteria with special emphasis on Streptomyces lividans. Biochim. Biophys. Acta 1843: 1750-1761.

2. Uppenberg J, Hansen MT, Patkar S, Jones TA. 1994. The sequence, crystal structure determination and refinement of two crystal forms of lipase B from Candida antarctica. Curr. Biol. 2: 293-308.

3. Emond S. 2010. New efficient recombinant expression system to engineer Candida antarctica lipase B. Appl. Environ. Microbiol. 76: 2684-2687.

4. Liu ZQ, Zheng XB, Zhang SP, Zheng YG, 2012. Cloning, expression and characterization of a lipase gene from the Candida antarctica ZJB09193 and its application in biosynthesis of vitamin A esters. Microbiol. Res. 167: 452-460.

5. Mertens N, Remaut E, Fiers W. 1995. Tight transcriptional control mechanism ensures stable high-level expression from 77 promoterbased expression plasmids. Biotechnology 13: 175-179.

6. Schäfer A, Tauch A, Jäger W, Kalinowski J, Thierbach G, Pühler A. 1994. Small mobilizable multi-purpose cloning vectors derived from the Escherichia coli plasmids pK18 and pK19: selection of defined deletions in the chromosome of Corynebacterium glutamicum. Gene 145: 69-73.

7. Hermann T. 2001. Proteome analysis of Corynebacterium glutamicum. Electrophoresis . 22: 1712-1723.

8. Watanabe K. 2009. Scanning the Corynebacterium glutamicum R genome for high-efficiency secretion signal sequences. Microbiology 155: 741-750.

9. Yim SS, Choi JW, Lee RJ, Lee YJ, Lee SH, Kim SY, et al. 2016. Development of a new platform for secretory production of recombinant proteins in Corynebacterium glutamicum. Biotechnol. Bioeng. 113: $163-172$.

10. Teramoto H, Watanabe K, Suzuki N, Inui M, Yukawa H. 2011. High yield secretion of heterologous proteins in Corynebacterium glutamicum using its own Tat-type signal sequence. Appl. Microbiol. Biotechnol. 91: 677-687.

11. Yukawa H, Inui M. 2013. Corynebacterium glutamicum: Biology and Biotechnology, vol. 23. Springer.

12. Liebl W, Sinskey AJ, Schleifer KH. 1992. Expression, secretion, and processing of staphylococcal nuclease by Corynebacterium 
glutamicum. J. Bacteriol. 174: 1854-1861.

13. Itaya H, Kikuchi Y. 2008. Secretion of Streptomyces mobaraensis pro-transglutaminase by coryneform bacteria. Appl. Microbiol. Biotechnol. 78: 621-625.

14. Hermann T. 2003. Industrial production of amino acids by coryneform bacteria. J. Biotechnol. 104: 155-172.

15. Billman-Jacobe H, Wang L, Kortt A, Stewart D, Radford A. 1995. Expression and secretion of heterologous proteases by Corynebacterium glutamicum. Appl. Environ. Microbiol. 61: 1610-1613.

16. van der Rest ME, Lange C, Molenaar D. 1999. A heat shock following electroporation induces highly efficient transformation of Corynebacterium glutamicum with xenogeneic plasmid DNA. Appl. Microbiol. Biotechnol. 52: 541-545.

17. Schafer A, Kalinowksi J, Simon R, Seep-Feldhaus AH, Puhler A. 1990. High-frequency conjugal plasmid transfer from gramnegative Escherichia coli to various gram-positive coryneform bacteria. J. Bacteriol. 172: 1663-1666.

18. Laemmli UK. 1970. Cleavage of structural proteins during the assembly of the head of bacteriophage T4. Nature 227: 680-685.

19. Stoytcheva M, Montero G, Zlatev R, León JÁ, Gochev V. 2012. Analytical Methods for Lipases Activity Determination: A Review. Curr. Anal. Chem. 8: 400-407.

20. Sigurgísladóttir S, Konráòsdóttir M, Jónsson Á, Kristjánsson JK, Matthiasson E. 1993. Lipase activity of thermophilic bacteria from icelandic hot springs. Biotechnol. Lett. 15: 361-366.

21. Sharma R, Chisti Y, Banerjee UC. 2001. Production, purification, characterization, and applications of lipases. Biotechnol. Adv. 19: 627-662.

22. Blank K, Morfill J, Gumpp H, Gaub HE. 2006. Functional expression of Candida antarctica lipase B in Eschericha coli. J. Biotechnol. 125: 474-483.

23. Ujiie A, Nakano H, Iwasaki Y. 2016. Extracellular production of Pseudozyma Candida antarctica lipase B with genuine primary sequence in recombinant Escherichia coli. J. Biosci. Bioeng. 121: 303-309.
24. Liu D, Schmid RD, Rusnak M. 2006. Functional expression of Candida antarctica lipase B in the Escherichia coli cytoplasm - A screening system for a frequently used biocatalyst. Appl. Microbiol. Biotechnol. 72: 1024-1032.

25. Riordan JF. 1977. The role of metals in enzyme activity. Annal. Clin. Lab. Sci. 7: 119-129.

26. Unthan S. 2014. Beyond growth rate 0.6: What drives Corynebacterium glutamicum to higher growth rates in defined medium. Biotechnol. Bioeng. 111: 359-371.

27. Watanabe K, Teramoto H, Suzuki N, Inui M, Yukawa H. 2013. Influence of SigB inactivation on Corynebacterium glutamicum protein secretion. Appl. Microbiol. Biotechnol. 97: 4917-4926.

28. Rotticci-Mulder JC, Gustavsson M, Holmquist M, Hult K, Martinelle M. 2001. Expression in Pichia pastoris of Candida antarctica lipase $\mathrm{B}$ and lipase $\mathrm{B}$ fused to a cellulose-binding domain. Protein Expr. Purif. 21: 386-392.

29. Han SJ. 2003. Expression and characterization of a novel enantioselective lipase from Acinetobacter species SY-01. Biochimie 85: 501-510.

30. Bora L, Bora M. 2012. Optimization of extracellular thermophilic highly alkaline lipase from thermophilic bacillus sp isolated from hotspring of Arunachal Pradesh, India. Braz. J. Microbiol. 43: 30-42.

31. Kanmani P, Kumaresan K, Aravind J. 2015. Gene cloning, expression, and characterization of the bacillus amyloliquefaciens PS35 lipase. Braz. J. Microbiol. 46: 1235-1243.

32. Rifaat HM, El-mahalawy AA, El-menofy HA, Donia SA. 2010. Production, optimization and partial purification of lipase from Fusarium oxysporum. J. Appl. Sci. Environ. Sanit. 5: 39-53.

33. Medyantseva EP, Vertlib MG, Budnikov GK. 1998. Metal ions as enzyme effectors. Russ. Chem. Rev. 67: 225-232.

34. Vieira Gomes AM, Souza Carmo T, Silva Carvalho L, Mendonça Bahia F, Parachin NS. 2018. Comparison of yeasts as hosts for recombinant protein production. Microorganisms 6. pii: E38. 